\title{
PERTUMBUHAN DAN NILAI GIZI Ganoderma lucidum PADA MEDIA LIMBAH MANGIUM
}

\section{(Growth and nutritious values of Ganoderma lucidum cultivated on medium of mangium wastes)}

\author{
$\mathrm{Oleh} / \mathrm{By}$ : \\ Djarwanto ${ }^{1)} \&$ Sihati Suprapti ${ }^{11}$ \\ ${ }^{1)}$ Pusat Penelitian dan Pengembangan Hasil Hutan, Jl. Gunung Batu No. 5, Bogor \\ Telp. 0251-8633378, Fax. 0251-8633413
}

Diterima 17 April 2009, disetujui 11 Agustus 2009

\begin{abstract}
Cultivation medium for $\mathrm{G}$. lucidum was made of mangium sandust, bark and mixed of them, were composted with $10 \%$ rice bran, $5 \%$ grind corn, $2 \%$ lime, $0.5 \%$ gypsum and sufficient distilled water. Biological conversion efficiency (BCE) was calculated on the base of mushroom's weight divided by dried weight of the medium and presented in percentage. The results showed that the mycelium growth on spawn of mangium sawdust was slower than that of mangium bark, however spawn on the mangium sawdust possessed a better quality. Mycelium growth was spread entirely both on the surface of spawn medium and cultivation medium at 4 weeks after inoculation. The first harvesting was carried out at 64 days after inoculation. Production rates of G. lucidum HHBI-322, HHBI-328 and HHBI-337 were low i.e. 18.68 grams to 40.86 grams, with the $B C E$ value between $9.8 \%$ to $17.1 \%$. Nutrition values, particularly protein and fat were varied about $9.7 \%-13.7 \%$ and $1.8 \%-4.5 \%$, respectively. Polysaccharide content, specifically glucan was around $6.95 \%$ $9.29 \%$.
\end{abstract}

Keywords: Mangium bark, medium, mushroom, growth, biological conversion efficiency.

\section{ABSTRAK}

Media pertumbuhan Ganoderma lucidum masing-masing dibuat dari serbuk kayu atau kulit kayu mangium. Kedalam serbuk kayu atau kulit kayu dan campuran keduanya, ditambahkan dedak, menir jagung, kapur, gips masing-masing $10 \%, 5 \%, 2 \%, 0,5 \%$ dan air suling secukupnya. Efisiensi konversi biologi (EB) dihitung berdasarkan berat jamur yang dihasilkan dibagi bobot media kering, dinyatakan dalam persen. Hasil penelitian menunjukkan bahwa pertumbuhan miselium jamur pada media bibit serbuk gergaji kayu lebih lambat dibandingkan dengan pada media bibit serbuk kulit kayu mangium, namun kualitas bibit yang dihasilkan dalam media serbuk gergaji lebih baik. Pertumbuhan miselium pada media bibit dan pada media kultivasi telah merata pada umur 4 minggu setelah inokulasi. Tubuh buah jamur sudah dapat dipanen pada umur 64 hari setelah inokulasi. Produksi jamur G. Iucidum HHBI-322, HHBI-328 dan HHBI-337 umumnya rendah yaitu 18,68 g-40,86 g dengan nilai EB 9,77\%-17,09\%. Nilai gizi jamur terutama kadar protein dan lemak masing-masing berkisar antara $9,71 \%-13,65 \%$ dan $1,82 \%-4,50 \%$. Polisakarida yang terdapat pada $G$. lucidum terutama glukan berkisar antara $6,95 \%-9,29 \%$.

Kata Kunci: Kulit mangium, media, jamur, pertumbuhan, efisiensi konversi biologi. 


\section{PENDAHULUAN}

Ganoderma adalah jamur berkhasiat obat dan telah diketahui nilai manfaatnya. Jamur tersebut telah digunakan sebagai bahan obat tidak beracun (nontoxic medicine) yang bermanfaat untuk organ tubuh bagian dalam, meningkatkan daya ingat, pendengaran, penglihatan dan penciuman (Liu, 1993). Menurut Chang dan Miles (2004), miselium dan tubuh buah jamur $G$. lucidum memiliki senyawa bioaktif yang berkhasiat obat sebagai antitumor, antihipertensi, dan anti-HIV (buman immunodeficiency virus). Di China dan Jepang, jamur tersebut telah lama digunakan sebagai obat tradisional untuk berbagai penyakit (Hattori, 1997). Komponen utama G. Lucidum mampu mencegah dan meredakan penyakit (Chang dan Miles, 2004). Jamur tersebut telah diperdagangkan dalam bentuk tablet, cairan, tonik atau minuman, serta teh celup (Liu, 1993; Chang, 1993). Indonesia telah mengimpor produk jamur tersebut dalam bentuk irisan jamur kering, kemasan kapsul, salep, pasta gigi, minuman dan cairan injeksi sejak beberapa tahun lalu (Suprapti et al., 2008).

Di Indonesia penelitian budidaya jamur berkhasiat obat belum banyak dilakukan. Kulit dan serbuk kayu mangium merupakan limbah pembalakan dan pengolahan kayu yang berpotensi untuk dimanfaatkan sebagai media tumbuh jamur. Ruhiyat dalam Muladi et al. (2001) menyatakan bahwa biomassa total Acacia mangium pada umur 5-7 tahun berkisar antara $60,469-95,846$ ton/ha, diantaranya kulit kayu sebesar $7,282-8,836$ ton/ ha $(9,22 \%-13,46 \%)$. Pemanfaatan limbah tersebut untuk media jamur berkhasiat obat, diharapkan dapat memberikan nilai tambah. Penelitian budidaya jamur berkhasiat obat ( $G$. lucidum) ini menggunakan media serbuk gergaji dan kulit kayu mangium, yang diperkaya dengan dedak, menir jagung, gipsum dan kapur, dengan tujuan untuk mengetahui pertumbuhan, produktivitas dan nilai gizinya.

\section{BAHAN DAN METODE}

\section{A. Bahan}

\section{Kulit dan serbuk kayu}

Kulit kayu mangium diambil dari areal hutan tanaman, PT Musi Hutan Persada di Kabupaten Muara Enim, Sumatera Selatan. Kulit kayu tersebut di potong-potong kemudian digiling sampai berukuran seperti serbuk gergaji. Serbuk gergaji kayu mangium dikumpulkan dari penggergajian Pusat Litbang Hasil Hutan Bogor.

\section{Isolat jamur}

Jamur yang diteliti yaitu $G$. lucidum hasil koleksi dan diberi kode Hasil Hutan Bogor Indonesia yang selanjutnya disingkat HHBI-266, HHBI-322, HHBI-328 dan HHBI-337.

\section{Alat}

Alat yang digunakan dalam penelitian ini antara lain labu Kyeldahl, autoklaf, soxlet, HPLC, oven dan timbangan analit. 


\section{B. Metode}

\section{Media bibit}

Media bibit dibuat dari serbuk gergaji kayu, serbuk kulit kayu mangium, dedak, $\mathrm{CaCO}_{3}$, gips dan air suling secukupnya, dengan komposisi sebagai berikut:

a. Serbuk gergaji + dedak $10 \%+\mathrm{CaCO}_{3} 1,5 \%+$ gips $0,5 \%+$ air suling.

b. Serbuk kulit kayu + dedak $10 \%+\mathrm{CaCO}_{3} 1,5 \%+$ gips $0,5 \%+$ air suling.

Masing-masing komposisi media dicampur sampai merata, kemudian dimasukkan ke dalam botol kaca sebanyak 150 gram per botol dan ditutup dengan kapas steril, selanjutnya disterilkan dalam autoklaf pada suhu $121^{\circ} \mathrm{C}$ dan tekanan 1,5 atmosfir selama 30 menit. Media steril yang telah dingin diinokulasi Ganoderma lucidum HHBI-266, HHBI-322, HHBI-328 dan HHBI-337. Pertumbuhan miselium diamati setiap hari sampai pertumbuhan miseliumnya memenuhi seluruh permukaan media. Setelah miselium tumbuh merata dan tebal maka bibit tersebut siap untuk diinokulasikan pada media kultivasi.

\section{Media kultivasi}

Media kultivasi dibuat dari campuran serbuk kulit kayu, serbuk gergaji, dedak, menir jagung, kapur, gips dan air suling, dengan komposisi seperti pada Tabel 1.

\section{Tabel1. Komposisi media kultivasi}

\section{Table 1. Composition of cultivation media}

\begin{tabular}{|c|c|c|c|c|c|c|}
\hline \multirow{2}{*}{ Media } & \multicolumn{5}{|c|}{ Komposisi (Composition), \% } \\
\cline { 2 - 7 } & $\begin{array}{c}\text { Serbuk kulit } \\
\text { (Wood bark } \\
\text { powder) }\end{array}$ & $\begin{array}{c}\text { Serbuk gergaji } \\
\text { (Wood sawdust) }\end{array}$ & $\begin{array}{c}\text { Dedak } \\
\text { (Ricebran) }\end{array}$ & $\begin{array}{c}\text { Menir jagung } \\
\text { (Ground corn) }\end{array}$ & $\begin{array}{c}\text { Gipsum } \\
\text { (Gypsum) }\end{array}$ & $\begin{array}{c}\text { Kapur } \\
\text { (Lime) }\end{array}$ \\
\hline A & 82,50 & 0 & 10 & 5 & 0,5 & 2 \\
B & 61,87 & 20,63 & 10 & 5 & 0,5 & 2 \\
C & 41,25 & 41,25 & 10 & 5 & 0,5 & 2 \\
D & 20,63 & 61,87 & 10 & 5 & 0,5 & 2 \\
E & 0 & 82,50 & 10 & 5 & 0,5 & 2 \\
\hline
\end{tabular}

Masing-masing komposisi media dicampur sampai merata dengan penambahan air suling secukupnya sampai dapat dikepal, kemudian dimasukkan ke dalam kantong plastik PVC sebanyak 500 gram per kantong dan dikemas seperti botol, kemudian disterilkan menggunakan autoklaf pada suhu $121^{\circ} \mathrm{C}$ dan tekanan 1,5 atmosfir selama 30 menit. Media steril yang telah dingin diinokulasi bibit jamur Ganoderma lucidum HHBI-266, HHBI-322, HHBI-328 dan HHBI-337.

\section{Pengamatan}

Pertumbuhan miselium diamati setiap hari sampai pertumbuhan miseliumnya memenuhi seluruh permukaan media. Setelah miselium tumbuh merata dan tebal kantong plastik dirobek di bagian atas atau leher. Pertumbuhan tubuh buah diamati setiap hari setelah primordianya tumbuh. 


\section{Analisa kimia}

Tubuh buah masing-masing isolat jamur (HHBI-266, HHBI-322, HHBI-328 dan HHBI-337) yang berasal dari lima media, dicampurkan lalu digiling untuk ditetapkan nilai gizinya. Analisis dilakukan di laboratorium kimia makanan Puslitbang Gizi dan Makanan, Bogor. Penetapan kadar protein dilakukan dengan metode Kjeldahl menurut AOAC-14067, kadar lemak dengan metode Soxhlet menurut AOAC-14066 (Anonimus, 1984), kadar karbohidrat (polisakarida) dengan metode HPLC dan asam folat dengan metode Mikrobiologi.

\section{Analisa data}

Data pertumbuhan miselium (\%) di permukaan media bibit dianalisa menggunakan rancangan faktorial $2 \times 4$ (media bibit dan isolat jamur), dengan lima ulangan. Sedangkan data pertumbuhan miselium (\%) di permukaan media kultivasi dianalisa menggunakan rancangan faktorial 5x4 (komposisi media kultivasi dan isolat jamur), dengan lima ulangan.

Efisiensi konversi biologi (EB) dihitung berdasarkan berat tubuh buah jamur segar dibagi berat bahan media kultivasi kering dan dinyatakan dalam persen. Sedangkan fruitbody conversion rate (FCR) dihitung berdasarkan berat tubuh buah jamur kering dibagi berat bahan media kultivasi kering dan dinyatakan dalam persen.

\section{HASIL DAN PEMBAHASAN}

\section{A. Pertumbuhan Miselium Jamur Ganoderma lucidum Pada Media Bibit}

Rata-rata pertumbuhan miselium di permukaan media bibit tercantum pada Tabel 2 dan 3. Pertumbuhan miselium tersebut terlihat memenuhi permukaan media pada umur empat minggu. Pertumbuhan miselium pada serbuk gergaji kayu mangium tersebut cenderung lambat dibandingkan dengan pertumbuhan miselium HHBI-333 yang telah merata pada minggu ketiga (17 hari) setelah inokulasi (Suprapti et al., 2008).

Tabel 2. Pertumbuhan miselium of Ganoderma lucidum pada media bibit Table 2. Mycelium growth of Ganoderma lucidum on spawn media

\begin{tabular}{|c|l|c|c|c|c|}
\hline \multirow{2}{*}{$\begin{array}{c}\text { Media } \\
\text { (Medium) }\end{array}$} & Acacia mangium & \multicolumn{4}{|c|}{$\begin{array}{c}\text { Persentase pertumbuhan miselium pada umur } \\
\text { (Percentage of mycelium growth on age), minggu (week) }\end{array}$} \\
\cline { 3 - 6 } & & 1 & 2 & 3 & 4 \\
\hline a & $\begin{array}{l}\text { Serbuk gergaji kayu } \\
\text { (Wood sawdust) }\end{array}$ & $9,20 \mathrm{a}$ & $54,10 \mathrm{a}$ & $88,70 \mathrm{a}$ & $100 \mathrm{a}$ \\
\hline $\mathrm{b}$ & $\begin{array}{l}\text { Serbuk kulit kayu } \\
\text { (Wood bark powder) }\end{array}$ & $16,70 \mathrm{~b}$ & $66,55 \mathrm{~b}$ & $98,30 \mathrm{~b}$ & $100 \mathrm{a}$ \\
\hline
\end{tabular}

Keterangan (Remarks): Angka-angka dalam masing-masing kolom yang diikuti oleh huruf sama tidak berbeda nyata pada uji Tukey $\mathrm{p} \leq 0.05$ (Numbers within an each column followed by the same letter, means not-significant difference, Tukey test $p \leq 0.05$ ) 
Hasil analisis statistik menunjukkan bahwa media bibit dan isolat jamur mempengaruhi pertumbuhan miselium pada umur 1,2 dan 3 minggu ( $\mathrm{P} \leq 0.05)$. Uji beda Tukey $(\mathrm{p} \leq 0.05)$ menunjukkan bahwa pertumbuhan miselium jamur yang diinokulasikan pada media serbuk gergaji kayu lebih lambat dibandingkan dengan pada media serbuk kulit kayu mangium (Tabel 2). Hal ini mungkin disebabkan ukuran partikel serbuk kayu lembut atau kecil sehingga media menjadi padat, akibatnya miselium sulit menembus ke dalam media tersebut. Sedangkan pada media serbuk kulit kayu, ukuran partikel lebih besar, media sulit dipadatkan dan keadaannya menjadi berpori sehingga pertumbuhan miselium cepat menyebar ke seluruh permukaan media tetapi tipis. Pertumbuhan miselium pada media serbuk gergaji kayu lebih cepat tebal sehingga pertumbuhan tubuh buah lebih cepat. Oleh karena itu, untuk membuat bibit lebih baik digunakan serbuk gergaji kayu.

Pertumbuhan miselium empat isolat jamur pada media bibit terlihat bervariasi. Uji beda Tukey menunjukkan bahwa isolat jamur mempengaruhi pertumbuhan miselium pada umur 1 , 2 dan 3 minggu (Tabel 3). Pertumbuhan miselium paling lambat dijumpai pada isolat HHBI337.

Table 3. Pertumbuhan miselium empat isolat Ganoderma lucidum pada media bibit Table 3. Mycelium growth of four Ganoderma lucidum isolates on spawn media

\begin{tabular}{|c|c|c|c|c|}
\hline $\begin{array}{c}\text { Isolat jamur } \\
\text { (Mushroom } \\
\text { isolate) }\end{array}$ & \multicolumn{4}{|c|}{$\begin{array}{c}\text { Persentase pertumbuhan miselium pada umur } \\
\text { Percentage of mycelium growth on age), minggu (week) }\end{array}$} \\
\cline { 2 - 5 } & 1 & 2 & 3 & 4 \\
\hline HHBI-266 & $14,20 \mathrm{bc}$ & $67,90 \mathrm{~b}$ & $97,10 \mathrm{~b}$ & $100 \mathrm{a}$ \\
HHBI-322 & $11,20 \mathrm{ab}$ & $46,30 \mathrm{a}$ & $96,00 \mathrm{~b}$ & $100 \mathrm{a}$ \\
HHBI-328 & $21,30 \mathrm{c}$ & $86,10 \mathrm{~b}$ & $97,50 \mathrm{~b}$ & $100 \mathrm{a}$ \\
HHBI-337 & $5,10 \mathrm{a}$ & $41,00 \mathrm{a}$ & $83,40 \mathrm{a}$ & $100 \mathrm{a}$ \\
\hline
\end{tabular}

Keterangan (Remarks): Angka-angka dalam masing-masing kolom yang diikuti oleh huruf sama tidak berbeda nyata pada uji Tukey $\mathrm{p} \leq 0.05$ (Numbers within an each column followed by the same letter, means not-significant difference, Tukey test $p \leq 0.05$ )

\section{B. Pertumbuhan Jamur pada Media Kultivasi}

Rata-rata pertumbuhan miselium di permukaan media kultivasi tercantum pada Tabel 4 dan 5. Hasil analisis statistik menunjukkan bahwa media kultivasi dan isolat jamur mempengaruhi pertumbuhan miselium pada umur 1,2 dan 3 minggu ( $\mathrm{p} \leq 0.05$ ). Uji beda Tukey $(\mathrm{p} \leq 0.05)$ menunjukkan bahwa pertumbuhan miselium jamur yang lambat didapatkan pada media C (umur 1 minggu) dan media $\mathrm{D}$ dan $\mathrm{E}$ (umur 2 dan 3 minggu) seperti tecantum pada Tabel 4. Pada Tabel 5 terlihat bahwa pertumbuhan miselium yang lambat terjadi pada isolat HHBI-322.

Pada umur empat minggu setelah inokulasi telah nampak primordia (bakal tubuh buah) yang menembus kapas penutup sehingga media tersebut langsung diletakkan di ruang penumbuhan tubuh buah tanpa dibuka tutupnya. Tubuh buah dipanen setelah masak petik yaitu apabila bagian ujung atau tepi tubuh buah telah berwarna coklat kemerahan. Jamur tersebut mulai dipanen pada umur 37 hari dari munculnya primordia tersebut atau umur 64 hari setelah inokulasi. Tubuh buah jamur isolat HHBI-266 tidak ditimbang karena ukurannya 
sangat kecil dan tidak berkembang. Sedangkan tubuh buah yang tumbuh pada media A dan B nampak sangat kecil, menempel pada media dan sering hanya didapatkan tangkai yang memanjang, sehingga jamur tersebut juga tidak ditimbang. $\mathrm{Hal}$ ini mungkin disebabkan karena media cepat mengering akibat kurang padat atau mungkin makanan yang terdapat di dalam media tidak cukup untuk pertumbuhan dan perkembangan primordia. Data bobot tubuh buah jamur, nilai efisiensi konversi biologinya (EB) dan nilai fruit body conversion rate (FCR) tercantum pada Tabel 6.

Tabel 4. Pertumbuhan miselium jamur pada media kultivasi Table 4. Mycelium growth of mushroom on cultivation media

\begin{tabular}{|c|c|c|c|c|}
\hline \multirow{2}{*}{$\begin{array}{c}\text { Media } \\
\text { (Medium) }\end{array}$} & \multicolumn{4}{|c|}{$\begin{array}{c}\text { Persentase pertumbuhan miselium pada umur } \\
\text { Percentage of mycelium growth on age, minggu (week) }\end{array}$} \\
\cline { 2 - 5 } & 1 & 2 & 3 & 4 \\
\hline $\mathrm{A}$ & $6,75 \mathrm{c}$ & $60,90 \mathrm{c}$ & $96,30 \mathrm{~b}$ & $100 \mathrm{a}$ \\
$\mathrm{B}$ & $5,85 \mathrm{bc}$ & $79,80 \mathrm{~d}$ & $96,95 \mathrm{~b}$ & $100 \mathrm{a}$ \\
$\mathrm{C}$ & $3,55 \mathrm{a}$ & $33,50 \mathrm{~b}$ & $94,80 \mathrm{~b}$ & $100 \mathrm{a}$ \\
$\mathrm{D}$ & $4,05 \mathrm{ab}$ & $20,15 \mathrm{a}$ & $68,60 \mathrm{a}$ & $100 \mathrm{a}$ \\
$\mathrm{E}$ & $4,40 \mathrm{ab}$ & $21,35 \mathrm{a}$ & $62,20 \mathrm{a}$ & $100 \mathrm{a}$ \\
\hline
\end{tabular}

Keterangan (Remarks): Angka-angka dalam masing-masing kolom yang diikuti oleh huruf sama tidak berbeda nyata pada uji Tukey $\mathrm{p} \leq 0.05$ (Numbers within an each column followed by the same letter, means not-significant difference, Tukey test $p \leq 0.05), \mathrm{A}, \mathrm{B}, \mathrm{C}, \mathrm{D}$ dan E mengikuti Tabel 1 ( $A, B, C, D$ and E refer to Table 1).

Table 5. Pertumbuhan miselium empat isolat jamur pada media kultivasi Table 5. Mycelium growth of four mushroom isolates on spawn media

\begin{tabular}{|l|r|r|c|c|}
\hline \multirow{2}{*}{$\begin{array}{c}\text { Isolat jamur } \\
\text { (Mushroom isolate) }\end{array}$} & \multicolumn{4}{|c|}{$\begin{array}{c}\text { Persentase pertumbuhan miselium pada umur } \\
\text { (Percentage of mycelium growth on age), minggu (week) }\end{array}$} \\
\cline { 2 - 5 } & 1 & 2 & 3 & 4 \\
\hline HHBI-266 & $3,16 \mathrm{~b}$ & $39,20 \mathrm{~b}$ & $80,20 \mathrm{a}$ & $100 \mathrm{a}$ \\
HHBI-322 & $0,76 \mathrm{a}$ & $25,48 \mathrm{a}$ & $79,44 \mathrm{a}$ & $100 \mathrm{a}$ \\
HHBI-328 & $14,80 \mathrm{c}$ & $73,08 \mathrm{c}$ & $98,24 \mathrm{~b}$ & $100 \mathrm{a}$ \\
HHBI-337 & $0,96 \mathrm{a}$ & $34,80 \mathrm{~b}$ & $77,20 \mathrm{a}$ & $100 \mathrm{a}$ \\
\hline
\end{tabular}

Keterangan (Remarks): Angka-angka dalam masing-masing kolom yang diikuti oleh huruf sama tidak berbeda nyata pada uji Tukey $\mathrm{p} \leq 0.05$ (Numbers witbin an each column followed by the same letter, means not-significant difference, Tukey test $p \leq 0.05$ ).

Nilai EB HHBI-322 yang dibudidayakan pada media C dan E (masing-masing 12,9\% dan 17,08\%) lebih tinggi dibandingkan dengan laporan Suprapti et al. (2008) yang dibudidayakan pada kulit mangium dari limbah industri pulp masing-masing berkisar antara 8,08 - 8,92 dan 13,56 - 14,38. Sedangkan nilai EB HHBI-328 pada media C dan E (masingmasing 8,66\% dan 9,62\%) lebih rendah dibandingkan dengan laporan Suprapti et al. (2008) 
pada kulit mangium dari limbah industri pulp masing-masing berkisar antara $9,78 \%-10,60 \%$ dan $15,05 \%-16,76 \%$.

Table 6. Rata-rata pertumbuhan tubuh buah jamur Ganoderma lucidum Table 6. The average fruit body growth of Ganoderma lucidum

\begin{tabular}{|c|c|c|c|c|c|c|}
\hline \multirow{2}{*}{$\begin{array}{c}\text { Isolat jamur } \\
\text { (Mushroom } \\
\text { isolate) }\end{array}$} & \multirow{2}{*}{$\begin{array}{c}\text { Media } \\
\text { (Medium) }\end{array}$} & \multirow{2}{*}{$\begin{array}{c}\text { Jumlah tubuh } \\
\text { buah (Number } \\
\text { of fruit body) }\end{array}$} & \multicolumn{2}{|c|}{ Bobot (Weight), gram } & \multirow{2}{*}{$\begin{array}{c}\text { EB } \\
(B E), \\
\%\end{array}$} & \multirow{2}{*}{$\begin{array}{c}\text { FCR } \\
(\%)\end{array}$} \\
\hline & & & $\begin{array}{l}\text { Segar } \\
\text { (Fresh) }\end{array}$ & $\begin{array}{c}\text { Kering } \\
(D r y)\end{array}$ & & \\
\hline \multirow[t]{5}{*}{ HHBI-322 } & A & - & - & - & - & - \\
\hline & B & - & - & - & - & - \\
\hline & $\mathrm{C}$ & 1,2 & 27,83 & 13,04 & 12,90 & 6,04 \\
\hline & $\mathrm{D}$ & 1,4 & 34,54 & 14,37 & 15,89 & 6,61 \\
\hline & $\mathrm{E}$ & 2,0 & 36,56 & 16,07 & 17,08 & 7,61 \\
\hline \multirow[t]{5}{*}{ HHBI-328 } & A & - & - & - & - & - \\
\hline & B & - & - & - & - & - \\
\hline & $\mathrm{C}$ & 1 & 18,68 & 10,51 & 8,66 & 4,87 \\
\hline & $\mathrm{D}$ & 1 & 27,05 & 10,53 & 12,44 & 4,84 \\
\hline & $\mathrm{E}$ & 1 & 20,32 & 9,77 & 9,62 & 4,63 \\
\hline \multirow[t]{5}{*}{ HHBI-337 } & A & - & - & - & - & - \\
\hline & B & 1,6 & 31,64 & 13,91 & 16,07 & 7,06 \\
\hline & $\mathrm{C}$ & 1 & 30,16 & 14,69 & 13,98 & 6,81 \\
\hline & D & 1 & 40,86 & 17,09 & 18,80 & 7,86 \\
\hline & $\mathrm{E}$ & 1 & 38,34 & 16,65 & 18,15 & 7,88 \\
\hline
\end{tabular}

Keterangan (Remarks): EB (BE) = Efisiensi konversi biologi (Biological conversion efficiency), $F C R=$ fruit body conversion rate, $-=$ tubuh buah berupa tangkai dan tudung tidak berkembang (Fruit body consist stipe and pileus not develop ), A, B, C, D dan E mengikuti Tabel 1 ( $A, B, C, D$ and E refer to Table 1$)$.

\section{Nilai Gizi Ganoderma lucidum}

Analisis zat gizi jamur hanya dilakukan terhadap tudung dari tiga isolat tersebut yaitu Ganoderma lucidum HHBI-322, HHBI-328 dan HHBI-337. Sedangkan isolat HHBI-266 tidak di analisis karena tubuh buahnya hanya berupa tangkai yang memanjang dan apabila terdapat tudung ukurannya sangat kecil sehingga bahan tersebut tidak mencukupi kebutuhan sampel. Data zat gizi jamur disajikan pada Tabel 7. Kadar protein dan lemak tertinggi dijumpai pada G. Iucidum HHBI-337. Sedangkan kadar protein dan lemak yang terdapat pada G. lucidum HHBI-322 dan HHBI-328 hampir sama. Hal mungkin disebabkan karena kedua isolat ini termasuk strain yang sama sebab dilihat dari bentuk tubuh buahnya yang mirip. Polisakarida merupakan salah satu komponen pharmaceuticals dari jamur. Lin (1993) menyatakan bahwa polisakarida memiliki berbagai efek pharmacological seperti menghambat kanker melalui peningkatan ketahanan tubuh, mempertahankan kekebalan tubuh. Cochran (1978) menyebutkan bahwa polisakarida berkaitan dengan aktivitas antitumor. Dalam analisis 
polisakarida hanya ditemukan glucan yang memiliki sifat tersebut. Nilai glucan tertinggi didapatkan pada Ganoderma lucidum HHBI-328. Menurut Buswell dan Chang (1993) glucan dapat menurunkan tekanan darah, dan Beta glucan memiliki sifat antitumor.

Tabel 7. Nilai gizi G. lucidum dalam gram/100 gram bahan Table 7. Nutrition value of $\mathrm{G}$. lucidum in gram per 100 grams material

\begin{tabular}{|l|c|c|c|}
\hline \multirow{2}{*}{\multicolumn{1}{c|}{ Kandungan gizi }} & \multicolumn{3}{|c|}{ Isolat jamur (Mushroom isolate) } \\
\cline { 2 - 4 } & HHBI-322 & HHBI-337 & HHBI-328 \\
\hline Protein (Protein) & 10,82 & 13,65 & 9,71 \\
Lemak (Fat) & 1,82 & 4,50 & 1,85 \\
Asam folat (Folic acid) & $0,505^{*}$ & $0,531^{*}$ & $0,557^{*}$ \\
Air (Water) & 9,52 & 9,77 & 16,15 \\
Abu (Asb) & 1,18 & 2,71 & 1,43 \\
\hline Polisakarida & & & \\
(Polysaccharide): & & & \\
Glucan & 6,95 & 7,09 & 9,29 \\
Xylan & 2,09 & 2,84 & 2,79 \\
Galaktan & 9,39 & 11,56 & 12,26 \\
Araban & 4,59 & 5,60 & 7,63 \\
Mannan & 3,29 & 5,25 & 6,66 \\
\hline
\end{tabular}

Keterangan (Remarks): Data merupakan rata-rata dari dua ulangan (Data represent average of two replicates $),{ }^{*}=\mathrm{mg} / 100 \mathrm{~g}$.

\section{KESIMPULAN}

Pertumbuhan miselium jamur pada media bibit serbuk gergaji kayu lebih lambat dibandingkan serbuk kulit kayu mangium, namun kualitas bibit dalam serbuk kayu lebih baik. Pertumbuhan miselium tersebut memenuhi permukaan media bibit dan menebal pada umur 4 minggu setelah inokulasi.

Sedangkan pertumbuhan miselium jamur pada media kultivasi telah merata pada umur 4 minggu setelah inokulasi. Tubuh buah jamur mulai dipanen setelah masak petik yaitu pada umur 64 hari setelah inokulasi. Produksi jamur Ganoderma lucidum HHBI-322, HHBI-328 dan HHBI-337 umumnya rendah yaitu berkisar antara 18,68 - 40,86 g dengan nilai efisiensi konversi biologi berkisar antara 9,77-17,09\%. Didapatkan bahwa tudung tubuh buah $G$. lucidum $\mathrm{HHBI}-266$ tidak berkembang.

Kandungan protein dan lemak jamur masing-masing berkisar antara $9,71-13,65 \%$ dan $1,82-4,50 \%$. Polisakarida yang terdapat pada G. Lucidum terutama glukan memikili efek medis. Kadar glukan pada jamur tersebut berkisar antara 6,95-9,29\%. 


\section{DAFTAR PUSTAKA}

Anonimus. 1984. Official Methods of Analysis Association of Official Agricultural Chemists. AOAC: Protein-14066; Fat-14067. Washington DC. 1141 p.

Buswell, J.A. and S.T. Chang. 1993. Edible mushrooms: attributes and applications. p.: 297324. In Chang, S.T., J.A. Buswell and P.G. Miles (Eds.) Genetics and Breeding of Edible Mushrooms. Gordon and Breach Science Publishers.

Chang, S.T. 1993. Mushroom biology: The impact on the mushroom production and mushroom products. p.: 3-20. In Chang S.T., J.A. Buswell and S.W. Chiu (Eds.) Mushroom Biology and Mushroom Products. The Chinese University Press. Hong Kong.

Chang, S.T. and P.G. Miles. 2004. Mushrooms cultivation, nutritional value, medicinal effect, and environmental impack. Second Edition. 477 p. CRC Press. Boca Raton London New York Washington, D.C.

Cochran, K.W. 1978. Medical Effects. p.: 169-187. In Chang, S.T. and W.A. Hayes (Eds.) The Biology and Cultivation of Edible Mushrooms. Academic Press. New York.

Hattori M. 1997. Inhibitory effect of components from Ganoderma lucidum on the growth of human immunodeficiency virus (HIV) and the Protease Activity. p.: 128-135. In Mizuno, T., N. Ide and Y. Hasegawa (Eds.). Proceedings of the 1 st International Symposium on Ganoderma lucidum in Tokyo, November 17-18, 1997. Japan.

Lin, Z.B. 1993. Advances in the pharmacology of Tremella polysaccharides. p.: 293-298. In Chang, S.T., J.A. Buswell and S.W. Chiu (Eds.). Mushroom Biology and Mushroom Products. The Chinese University Press. Hong Kong.

Liu, G.T. 1993. Pharmacology and clinical uses of Ganoderma. p.: 267-273. In Chang, S.T., J.A. Buswell and S.W. Chiu (Eds.). Mushroom Biology and Mushroom Products. The Chinese University Press. Hong Kong.

Muladi, S., R. Amirta, E.T. Arung and Z. Arifin. 2001. Chemical component analysis of wood bark compost on waste of medium density fiberboard industry. Proceedings of seminar "Environment Conservation through Efficiency Utilization of Forest Biomass tanggal 13 Nopember 2000 di Yogyakarta. p.: 124-137. DEBUT Press Jogjakarta. Yogyakarta.

Suprapti, S., Djarwanto dan R. A. Pasaribu. 2008. Pemanfaatan kulit kayu mangium dari limbah industri pulp untuk media produksi Ganoderma lucidum. Jurnal Penelitian Hasil Hutan 26 (3): 263-276. Pusat Penelitian dan Pengembangan Hasil Hutan. Bogor. 